\title{
THE PASSAGE TO OTHER WORLDS: FROM MORAL EDIFICATION TO COLLAPSE OF ALL VALUES
}

\author{
Maria-Ana Tupan ${ }^{1} \backslash$ (iD \\ ${ }^{1}$ Habilitated Professor of the Doctoral School of Universitatea Alba Iulia, Alba Iulia, Romania
}

Received 6 September 2021

Accepted 18 September 2021

Published 30 September2021

\section{CorrespondingAuthor \\ Maria-Ana Tupan, \\ m_tupan@yahoo.com \\ DOI \\ 10.29121/granthaalayah.v9.i9.2021. 4263}

Funding: This research received no specific grant from any funding agency in the public, commercial, or not-for-profit sectors.

Copyright: (C) 2021 The Author(s). This is an open access article distributed under the terms of the Creative Commons Attribution License, which permits unrestricted use, distribution, and reproduction in any medium, provided the original author and source are credited.

\section{ABSTRACT}

\section{The Passage as Ethical Operator}

Is space relevant in a debate over the ethical dimension of a literary work? If we understand it as Foucault ${ }^{1}$, Lefebvre ${ }^{2}$, Soja ${ }^{3}$ or Marc Auger ${ }^{4}$ do, it is. In Andre Norton's The Crossroads of Time ${ }^{5}$, many worlds coexist as versions of an original earth, ruined by wars whose memories set agents under cover travelling across in order to defend what had remained of humanity besieged by monsters against a universal murderer, Kmoat Vo Pranj. The characters' psychic powers depend on their interference with the environment - an idea probably originating with quantum experiments whose results depend on the interference of the measuring equipment with the system. An agent talks about alternative histories in an ecological version which relates individuals' growth or success to favourable conditions in the world out there, to their or society's benefit.

Keywords: Passage, Worlds, Moral, Collapse, Values

\section{INTRODUCTION}

"But suppose", Saxton had set down his cup and now he leaned forward his eyes alight, "suppose such a man, born out of his time in his own world, were given the ability to move from one possibility line to another-would he not be doubly dangerous? Suppose you were born in an era in which your own society stifled your particular talents, giving you, as you thought, no proper outlet." Norton, Andre. (1956)

The passage to an ontologically distinct world engages both parties in an ethical relationship in a way which does not differ much from that between an individual and another human being.

The prop of ontological transfer is not just a narrative operator but a codifying device: the fall of Alice down a hole in the earth prepares the reader for the encounter with a lower reality of beasts, irrrationality and lawlessness; on the contrary, the children's access to Narnia through a wardrobe in C S Lewis's

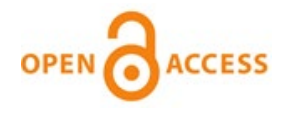

\footnotetext{
${ }^{1}$ Henri Lefebvre, La production de l'espace. in L'Homme et la société, N. 31-32, 1974. Sociologie de la connaissance marxisme et anthropolgie. pp. 15-32.

DOI : https://doi.org/10.3406/homso.1974.1855

${ }^{2}$ Henri Lefebvre, La production de l'espace. in L'Homme et la société, N. 31-32, 1974. Sociologie de la connaissance marxisme et anthropolgie. pp. 15-32.

DOI : https://doi.org/10.3406/homso.1974.1855

3Edward Soja, Thirdspace: Journeys to Los Angeles and other real-and imagined places. (Oxford: Blackwell.1996)

${ }^{4}$ Marc Augé. Non-Lieux, Introduction a une anthropologie de la surmodernité (Paris : Editions du Seuil, 1992)

5 Andre Norton. 1956, The Crossroads of Time (New York: ABE Books, 1956)
} 
The Chronicles of Narnia: The Lion, the Witch and the Wardrobe is suggestive of an abyss of worlds towards a core of Platonic metaphysical presence.

Born in Ulster and descending from a paternal grandfather who had migrated from Wales to Ireland, and a maternal grandfather who was a bishop, C. S. Lewis would maintain all his life an uneasy position between Christian faith and a fascination with the Celtic myths originating in pagan times. At the same time, he was intensely aware of the paradigmatic shift in contemporary physics from the picture of one stable world to worlds rising from the probability of wave interference, whether in Heisenberg's matrical model of the wave function (Figure 1) or in Schrödinger's model of Eigenstates realized in time through forking.

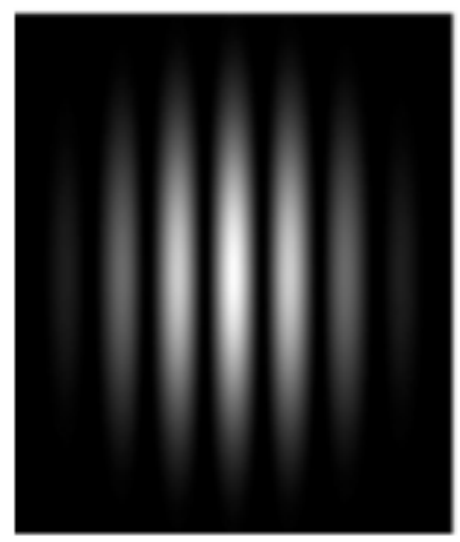

Figure 1 Interactive simulation of quantum interference.

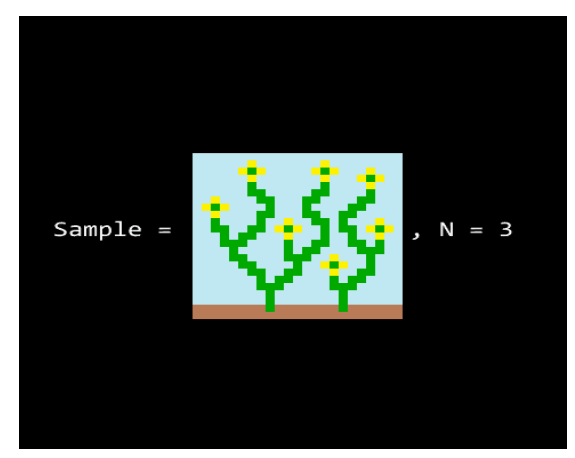

Figure 2 Wave function collapse

6

The Time and space of the multiverse take variable values as elements in the matrix. Interferences among worlds, modelled on the interference of states in the wave function, may result, for instance, in acts of justice which the subjects of a very strong and evil power cannot undertake, but which are in the power of a saviour from another world. Lewis says that his serial novel is not an allegory but an answer to the question: should a Christ figure land into this world, how would he restore the fallen Narnia of beasts and dissidents turned to stone by the hated White Witch? 
Time travel is best suited for moral judgement or axiological assessment as the phases belong to the same system. In Planet of the Apes (Michael Wilson \& Rod Serling, 1968), the protagonist travels in time to a decayed America. In Asimov's Pebble in the Sky (1950), the protagonist is projected into the future because of a leak from a nearby nuclear laboratory. Here he manages to prevent the destruction of the earth by psychopaths obsessing with power over the whole universe. His body carries the signs of an inferior technology - his teeth for instance are nor grafted directly on the jaw but fixed with wires onto their neighbours - but he is ethically superior as technology has turned people into soulless, infatuated controllers.

In the multiverse forking in time into autonomous states, as the Monitor muses in the television series, Crisis on Infinite Earths (2019), justice is suspended. Hugh Everett's model of the multiverse ${ }^{7}$ looks like a binary code. In the well-known thought experiment of Schrödinger's cat, there is only one realized state the moment the observer opens the box: the cat is either dead or alive. On the contrary, Everett's multiverse is one of relative states created by the forking or splitting of the results in relative states: the cat is only relatively alive because in the other universe emerging from forking it is dead. Both states are said to be realised. In Vonnegut's Slaughterhouse Five, for instance, Billy Pilgrim can find the relief brought by the travel from one timeline to another where the bombing of Dresden never happened, but in the one from which he escapes the tragic event is still there. This is not justice, this is escapism. Characters may be stranded in separate worlds that do not communicate among themselves, the ethical relationship to an otherness being thus suspended.

These earlier works of the postwar period are still familiar, in the sense that they show a certain predictability in their behaviour, some constant traits of character, an ethical design being projected over the space they inhabit Affinity is binding the individual to the space of his habitat and the earth to the whole universe through reciprocal influencing. Lewis's essay book Miracles. A Preliminary Study opens with a poem which he had published the previous year in a journal, where the earth is seen as being born of the universe but also as harbouring and incorporating meteors, bits of the outer space:

Among the hills a meteorite lies huge;

And moss has overgrown,

And wind and rain with touches light made soft,

The contours of the stone.

Thus, easily can Earth digest

A cinder of sidereal fire,

And make her translunary guest

The native of an English shire

Nor is it strange these wanderers

Find in her lap their fitting place,

For every particle that's hers

Came at the first from outer space

7 Everett, Hugh. "'Relative state' formulation of quantum mechanics". Reviews of Modern Physics. 29 (3), 1957, pp. 454-462. 


\section{All that is Earth has once been sky; \\ Down from the Sun of old she came, \\ Or from some star that travelled by \\ Too close to his entangling flame.}

Hence, if belated drops yet fall

From heaven, on these her plastic power

Still works as once it worked on all

The glad rush of the golden shower.

The imagery performs a conjugation of maternal and filial affection which calls to mind patterns from Celtic mythology of continuity: the endless Celtic knot (Figure 3 ) or the Celtic tree of life (Figure 4), which could serve as an emblem of the Celtic summer versus Narnia's winter (The Lion, the Witch and the Wardrobe, 1950).

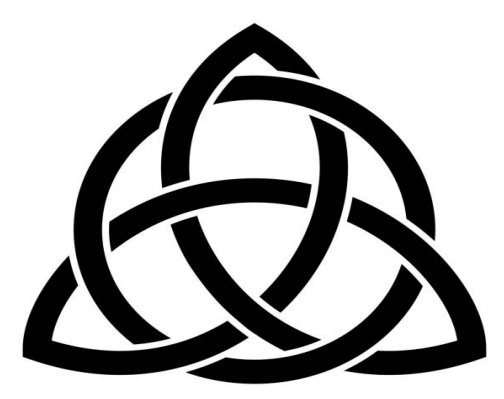

Figure 3 The Celtic Knot

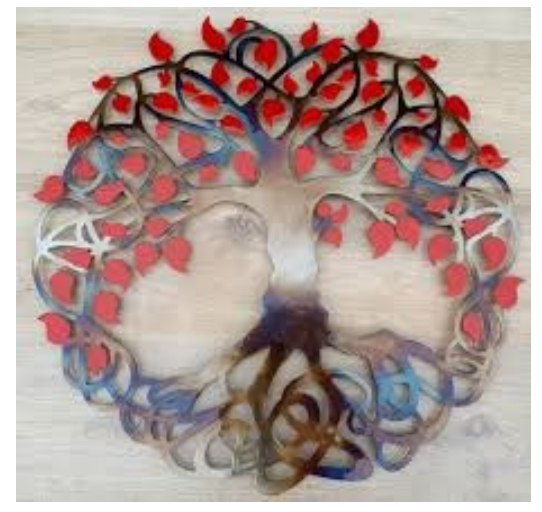

Figure 4 The Celtic Tree of Life

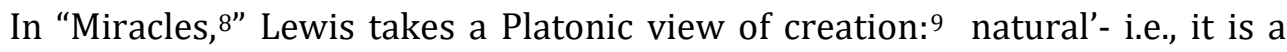
specimen of a class of things which God normally creates after a stable pattern" 10

Lewis goes by the book from the very circumstances of writing the Narnia chronicles, and the precedent is Lewis Carroll. As well as Rev. Charles Lutwidge

8 First published in 1947. A revised edition came out in 1960.

9 In Timaeus, the Demiurge creates the universe according to the paradigm, the Pythagorean Tetractys.

10 C.S. Lewis, Miracles. A Preliminary Study (London: Geoffrey Bles), 1947, p. 126 
Dodgson, who wrote the Alice books for the daughter of his friend, Dean Henry Liddell of Christ Church, C S Lewis dedicated the Narnia novels to his goddaughter, Lucy Barfield, the daughter of his teacher and friend, Owen Barfield.

The tone of Lucy's first conversation with the faun in Narnia sounds pretty much like Alice's talk with the March Hare, it is only that his misunderstanding of Narnia's guest's words has the effect of casting her casual remarks into a taxonomic and mythical scheme:

"Good evening, good evening," said the Faun. "Excuse me-I don't want to be inquisitive-but should I be right in thinking that you are a daughter of Eve?"

"My name's Lucy," said she, not quite understanding him.

"But you are-forgive me-you are what they call a girl?" asked the Faun.

"Of course, I'm a girl," said Lucy.

"You are in fact Human?"

"Of course, I'm human," said Lucy, still a little puzzled.

"To be sure, to be sure," said the Faun. "How stupid of me! But I've never seen a Son of Adam or a daughter of Eve before. [...], "Allow me to introduce myself. My name is Tumnus."

"I am very pleased to meet you, Mr. Tumnus," said Lucy.

"And may I ask, O Lucy, Daughter of Eve," said Mr. Tumnus, "how you have come into Narnia?"

"Narnia? What's that?" said Lucy.

"This is the land of Narnia," said the Faun, "where we are now; all that lies between the lamp-post and the great castle of Cair Paravel on the eastern sea. And you-you have come from the wild woods of the west?"

"I-I got in through the wardrobe in the spare room," said Lucy.

It is summer there."

"Meanwhile," said Mr. Tumnus, "it is winter in Narnia, and has been for ever so long, and we shall both catch cold if we stand here talking in the snow. Daughter of Eve from the far land of Spare Oom - where eternal summer reigns around the bright city of War Drobe, how would it be if you came and had tea with me?"

We may say that Lucy's semiotic language is mapped onto a symbolical one by the faun. His own name, Tumnus, has a compound Latin etymology: tum: then, at that time; nos: we', and num/nus: now. A myth will lie outside calendar time, being a constant, metaphysically full, signified.

Oom is a sacred symbol in Hindu Mythology: of Atman as of Brahman, of the ultimate reality, of consciousness.

Wardrobe is one more word which is granted an inner form/ meaning: War $\mathrm{D}[\mathrm{e}]$ robe - war of derobing/ divesting someone of status or ceremony.

Cair Paravel may be more sophisticated in its origin. Cair is probbaly a slightly different phonetic form of Welsh caer meaning castle, citadel. Was Cair Paravel coined as a foil to Caerleon? After all, why should Narnia have been created by a lion of all creatures? Maybe Caerleon, the castle of the lion, apart from making the lion an Arthur figure, also makes sense as the legitimate seat of authority which the White Witch (a fallen version of the Celtic White Goddess in a lapserian world) has replaced with Cair Paravel (the lowest in a hierarchy, the antonym of paramount). Avel has also been associated with Avelon, Arthur's seat - here, that which is beyond it. 
This is the moralised landscape of the Christian drama of salvation, with mythological props all the way, such as Father Christmas, who is the harbinger of the Saviour.

Narnia's true ruler - the great lion named Aslan, the Son of the Emperor Beyond the Sea - is returning at the Stone Table - reminiscent of Moses' stone tablets of the covenant with God and suggesting, like Peter, the rock on which a strong and enduring belief is founded. Aslan had founded Narnia - he is the true lord. The present castle is at the other pole of authoriuty, low, usurped by the witch. Things will come back to normal the moment Cair Paravel is seated by two daughters of Eve and two sons of Adam - the new Eves and Adams, reversing the fall. The children are the redeemers (Christ figures).

The protagonsits' hunt of the white stag as they reach mature age is symbolical of their spiritual quest. The white stag is an alchemical symbol, also painted on Richard II's heraldic emblem. It symbolizes the redemption of the spirit lost among pagan mythical figures and animals similar to Alice's initiation by the caterpillar - a serpant figure - leading to her emancipation from among the Darwinian animals. She dismisses her crazy company, replacing them with signs: a semiotic death in a packet of cards.

\section{The Multiverse and the Demise of Ethical Life. The Amoral Worlds of Simulacra}

The transfer through wormholes in the quantum universe only engages dimensions (of space and time) in futuristic SF, whereas postmodernist derealisation and deconstruction of metaphysics feeds into fantasy worlds of ontological instability, hyperreality and simulacra.

The passage is now a descent into a sham mode of existence, whether that means Doctor Parnassius' exploitation of people's own imagination (teleplay by Terry Gilliam and Charles McKeown) or "reality show": playing instead of living according to scripts of the creators of games as in Suzanne Collins' Hunger Games. The mirror or the stage ushers the audience into fictional narratives which deliberately rewrite wrong myths of the logocentric age, such as the Genesis, man's place in the universe, spiritual rebirth (with a Phoenix replaced by a mocking jay), revelation (instead of metaphor, a wardrobe is literalised as a designer's "haute couture"), the Eucharist, etc. The devaluation of all values does not leave ethics untouched, the plot of the lapse of humanity, its second fall, including betrayal, victimization, humiliation, famishing of one's neighbours - effect a dismal identification of humans with the horsemen of the apocalypse.

As well as in a medieval morality play,there are characters in The Chrisis on the Earths (2018) which stand for paragons of humanity's fundamental values - love destiny corage etc. - but these characters are unstable, they may be possessed. As if under a magic spell, Lyla even kills the Monitor as she is possessed by the antiMonitor. Biblical mythology is threaded with scientific tropes, sucb as the Vanishing Point where the paragons are taken - that is an archetypal matrix of symbols but also a quantic singularity. There is no brave new world after the apocalyptic end of the Flesh, on the contrary, the new beginning is a new Fall as Lex Luthor, a supervillain, takes Superman's place, forcing "destiny into rewriting wrong" its book of divine comedy. Characters are simply sliding under their anatgonists' masks,

The same downward, entropic spiral of full signifieds can be noticed in other cultures, for instance in the booming Indian movie industry. A popular TV serial, Simar's In-laws, starts from a display of identitarian marks of ethnicity: Indian beliefs, idols, festivals, food, wedding ceremony (Figure 5, Figure 6, Figure 7), 


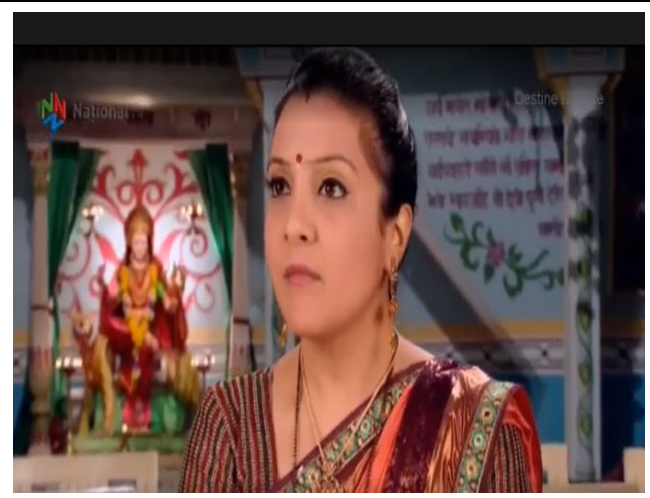

Figure 5

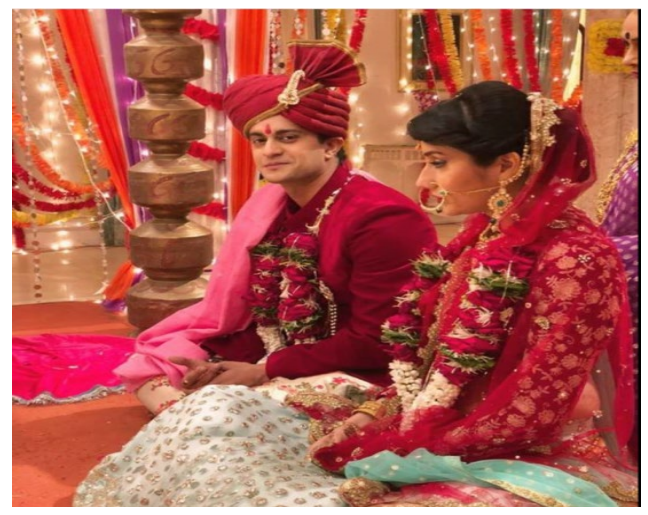

Figure 6

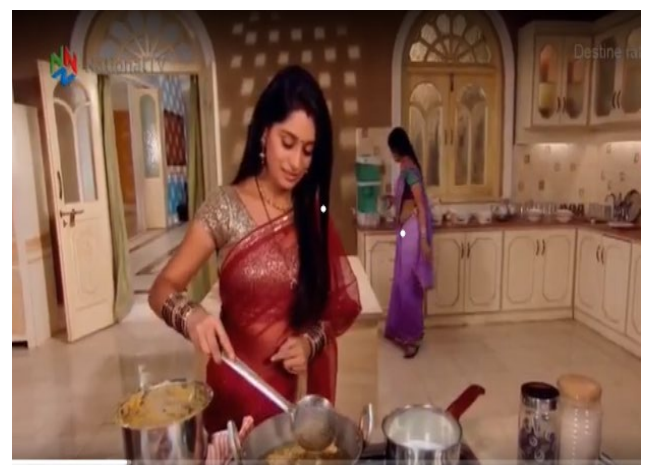

Figure 7

but, probably, concomitantly with the extension of the distribution network throughout Europe, from Romania to the United Kingdom, teleplay writer Anar Anand University changed dramtiaclly the course of events diving into the gothic atmosphere of black magic. The transformation demanded from one actor, Aadesh Chaudhry playing Vikrant, a character who cahanges from a well-meaning magistrate in love with Simar into a a wild creature, absolute for the destruction of his rival and of the woman he loves, made him quit the movie set altogether ... Hindu myths are replaced with stereotypes of European gothic: the vampire coming back to the earth in a coffin, drinking blood, suching to death a woman's blood, carrying emblems of secret rituals, such as the pentacle, and stamped with the number of the apocalyptic beast, 666 (Figure 8, Figure 9, Figure 10, Figure 11) 


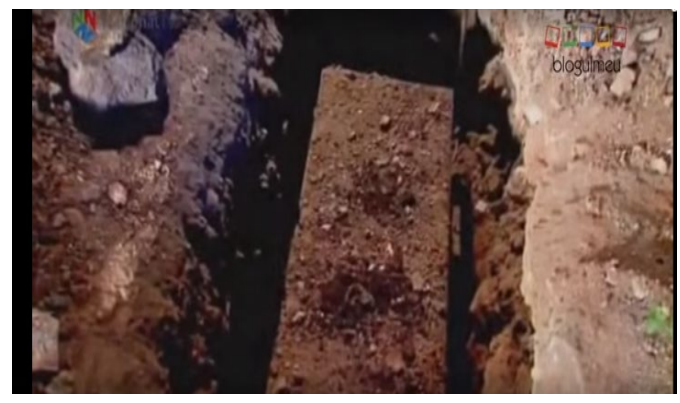

Figure 8

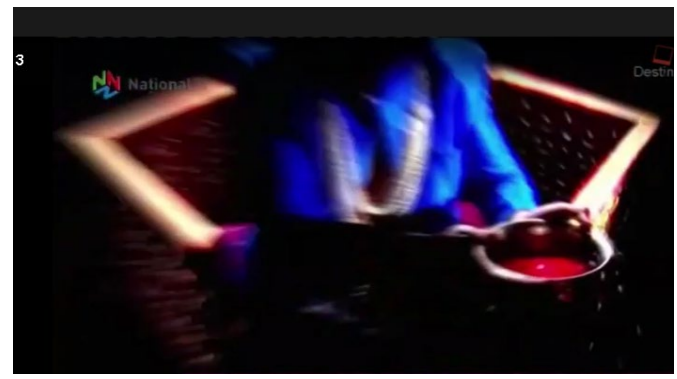

Figure 9

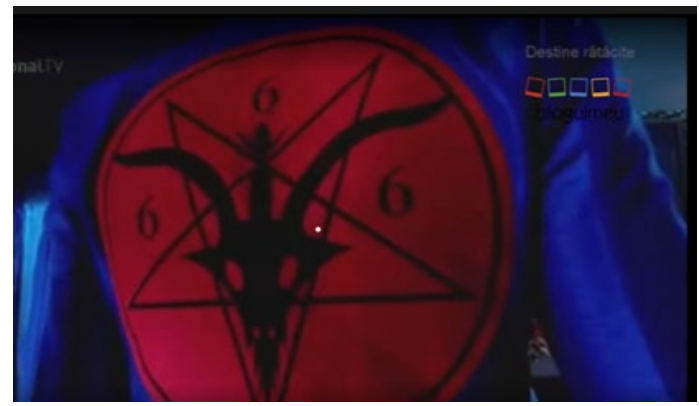

Figure 10

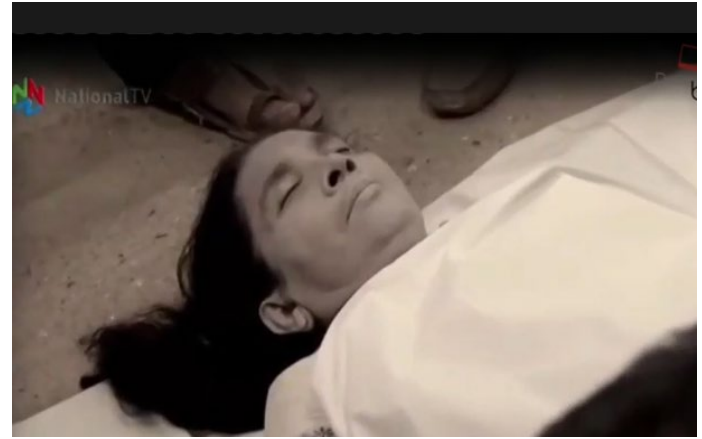

Figure 11

Familiar images cross borders and get distributed and consumed by an audience addicted to the parapharnalia of an amoral but thrilling show of gothic sensationalism. 


\section{REFERENCES}

Augé, Marc (1992). Non-Lieux, Introduction a une anthropologie de la surmodernité . Paris : Editions du Seuil.

Everett, Hugh (1957). "'Relative state' formulation of quantum mechanics". Reviews of Modern Physics. 29 (3), 1957, pp. 454-462. Retrieved from https://doi.org/10.1103/RevModPhys.29.454

Foucault, Michel. (1984). Dits et écrits," Des espaces autres " (conférence au Cercle d'études architecturales, 14 mars 1967), Architecture, Mouvement, Continuité, n " 5, octobre 1984, pp. 46-49.

Higgins, James E. (1966). "A Letter from C. S. Lewis". The Horn Book Magazine. October 1966.

Lefebvre, Henri (1974). La production de l'espace. in L'Homme et la société, N. 3132, 1974. Sociologie de la connaissance marxisme et anthropolgie. pp. 15-

32. Retrieved from https://doi.org/10.3406/homso.1974.1855

Lewis, C.S. (1947). Miracles. A Preliminary Study. London: Geoffrey Bles.

Norton, Andre. (1956), The Crossroads of Time. New York: ABE Books.

Soja, Edward. (1996). Thirdspace: Journeys to Los Angeles and other real-and imagined places. Oxford: Blackwell 